This is an open access article under the CC BY-NC-ND license

Issue IV, 22 November 2021

e-ISSN 2707-9481

Institute of Metallurgy and Ore Beneficiation, Satbayev University, Almaty, Kazakhstan

ISBN 978-601-323-252-2 https://doi.org/10.31643/2021.12

\author{
Almagul Ultarakova \\ "Institute of Metallurgy and Ore Beneficiation" JSC, \\ Satbayev University, Kazakhstan \\ E-mail: a.ultarakova@satbayev.university \\ ORCID ID 0000-0001-9428-8508
}

\author{
Nina Lokhova \\ "Institute of Metallurgy and Ore Beneficiation" JSC, \\ Satbayev University, Kazakhstan \\ E-mail: n.lokhova@satbayev.university \\ ORCID ID 0000-0001-9436-5462
}

\author{
Azamat Yessengaziyev \\ "Institute of Metallurgy and Ore Beneficiation" JSC, \\ Satbayev University, Kazakhstan \\ E-mail: a.esengaziev@satbayev.university \\ ORCID ID 0000-0002-4989-4119
}

\title{
Silica removal from waste of ilmenite concentrate pyrometallurgical processing
}

\begin{abstract}
The article presents the study results for alkaline leaching of fine ilmenite concentrate dusts from electric smelting. The physical and chemical properties of the dusts were studied using chemical and instrumental analysis methods. The dust composition was determined, X-ray phase analysis showed that the dust sample substance is in the X-ray amorphous state, iron is present in the trivalent state, and silicon is bound to magnesium. The dust sample study using a scanning electron microscope showed that part of the titanium is bound in a hard-to-disclose anasovite encapsulated in amorphous silicon oxide. The leaching study of electric smelting dust with sodium hydroxide solutions included the study of the effect of sodium hydroxide concentration, process duration, temperature, $S$ : $L$ ratio. The optimal conditions for dust leaching from electric smelting of ilmenite concentrate have been established: temperature $80-90{ }^{\circ} \mathrm{C}$, duration $90-120 \mathrm{~min}$, ratio $\mathrm{S}: \mathrm{L}=1: 5$, the concentration of sodium hydroxide solution $110-115 \mathrm{~g} / \mathrm{dm}^{3}$. The silicon extraction degree into the solution under these conditions was $77.7 \%$. The behavior of accompanying components of chromium, zinc, iron, and manganese during dust leaching was also studied. X-ray phase analysis of the cake after leaching shows almost complete amorphization of the leached product, the main phase is a solid solution of $\mathrm{Fe}_{2} \mathrm{O}_{3} \cdot \mathrm{TiO}_{2}$.

Keywords: fine dust, ilmenite concentrate, leaching, sodium hydroxide, silicon
\end{abstract}

Cite this article as: Ultarakova A.; Lokhova N.; Yessengaziyev A. (2021). Silica removal from waste of ilmenite concentrate pyrometallurgical processing. Challenges of Science. Issue IV, pp. 82-90. https://doi.org/10.31643/2021.12

\section{Introduction}

The largest producers of titanium sponge are China, Japan, Russia, Kazakhstan, the USA, and Ukraine [1-4], while one of the leading suppliers - the Kazakh enterprise Ust-Kamenogorsk Titanium and Magnesium Plant JSC (UKTMP JSC) accounts for about $18 \%$ of the world production of titanium sponge. Titanium concentrate is used as a raw material for titanium production; electric reduction smelting produces titanium slag and substandard cast iron. UKTMP JSC uses one-stage electric smelting of ilmenite concentrates to produce titanium slag and cast iron, the charge for smelting is supplied in a loose state, accompanied by high dust emissions. The silicon contained in the charge is sublimed in the smelting process of ilmenite concentrates at $1600-1700{ }^{\circ} \mathrm{C}$, and together with gases is taken into the gas duct system, it condenses in the form of amorphous silica $\mathrm{SiO}_{2}$ in scrubbers and enters thin bag filters. Dusts cannot be returned to the electrofusion process or fed to chlorinators due to the high silica content. High 
silica content in the first case will provoke boiling of the melt; in the second case, the presence of silica will adversely affect the quality of titanium tetrachloride produced during slag chlorination, because later the silicon will pass into titanium tetrachloride and worsen the grade of titanium sponge. The captured dust cannot be recycled back into the process, so it is stored together with other solid waste in designated areas, landfills. UKTMP JSC generates up to 76,000 tons of chloride waste annually at maximum capacity utilization, including about 600 tons of fine sleeve filter dust. Waste is eroded and dispersed by natural precipitation and wind, contaminating water and soil basins [5]. The company has to pay huge fines for the accumulated waste maintenance.

\section{Method (Participants, Instruments and Procedure)}

Methods of analysis: X-ray experimental data were obtained on BRUKERD8 ADVANCE apparatus using copper radiation at accelerating voltage $36 \mathrm{kV}$, current $25 \mathrm{~mA}$. X-ray fluorescence analysis was performed on Venus 200 PANalytical B.V. (PANalytycal B.V., Holland) spectrometer with wave dispersion. Chemical analysis of the samples was performed on an Optima 2000 DV inductively coupled plasma optical emission spectrometer (PerkinElmer, USA). The elemental and phase composition of the samples was mapped on a JXA-8230 electron probe micro analyzer (JEOL, Japan).

Experimental procedure: leaching experiments were performed in thermostatic reactors of $0.5 \mathrm{dm}^{3}$ volume. Slurry stirring was performed by a mechanical stirrer with an adjustable number of rotations. A certain amount of sodium hydroxide solution was poured into the reactor and heated to a predetermined temperature, upon reaching which a sample of dust was introduced and, while maintaining constant stirring of the pulp, leaching was performed. The pulp was filtered at the end of the process and the cake was washed with distilled water. The content of uncontrolled components in the washed cake was determined.

\section{Results and discussion}

The silicate base of electro smelting dust of ilmenite concentrates can be destructed by the method called alkaline desiliconization that consists in leaching the dust in sodium hydroxide solutions. The silicates should dissolve in this approach, with silicon going into the alkaline solution as a soluble sodium silicate, $\mathrm{Na}_{2} \mathrm{SiO}_{3}$, while titanium should remain in an insoluble residue.

Materials: sodium hydroxide grade "chemically pure" ("Kaustik" JSC, RF). Dust of fine cleaning of electric smelting of ilmenite concentrate, presented by Ust-Kamenogorsk Titanium and Magnesium Plant JSC, the content of the main components is given in Table 1.

Physical and chemical properties of electric smelting of ilmenite concentrate dust: the results of $X$ ray phase analysis of the dust are shown in Figure 1 and Table 2 . The data of $X$-ray phase analysis indicate that the substance of the dust sample is in the X-ray amorphous state and the background of the diffractogram is high. It should be noted that iron in the dust is present in the trivalent state, and the harmful impurity silicon is associated with magnesium.

Table 1. Content of the main components of electro smelting of ilmenite concentrate dust, wt. \%

\begin{tabular}{ccccccc}
\hline \multicolumn{7}{c}{ Content, wt. \% } \\
\hline $\mathrm{TiO}_{2}$ & $\mathrm{Fe}_{2} \mathrm{O}_{3}$ & $\mathrm{SiO}_{2}$ & $\mathrm{ZnO}$ & $\mathrm{MgO}$ & $\mathrm{Cr}_{2} \mathrm{O}_{3}$ & $\mathrm{MnO}_{2}$ \\
\hline 46.37 & 26.90 & 10.04 & 3.18 & 1.55 & 0.45 & 2.90 \\
\hline
\end{tabular}

The content of small impurities and the forms of incorporation into the dust phases of electrofusion of ilmenite concentrate were determined by electron microscopy (Figures 2-4). The presence of particles of solid solution $\mathrm{nFe}_{2} \mathrm{O}_{3}-\mathrm{mTiO}_{2}$ was established (Figure 3).

Anosovitis can be attributed to the phase, radiographically characterized as the system $\mathrm{Fe}=\mathrm{Mn}$ $\mathrm{TiO}$ [6] (Figure 2). It is noted that part of the anosovite particles is in a shell of silicon and zinc oxides (Figure 3 ), and part is in a shell of silicon, zinc, and lead oxides. In addition, rare-earth metal phosphates and 


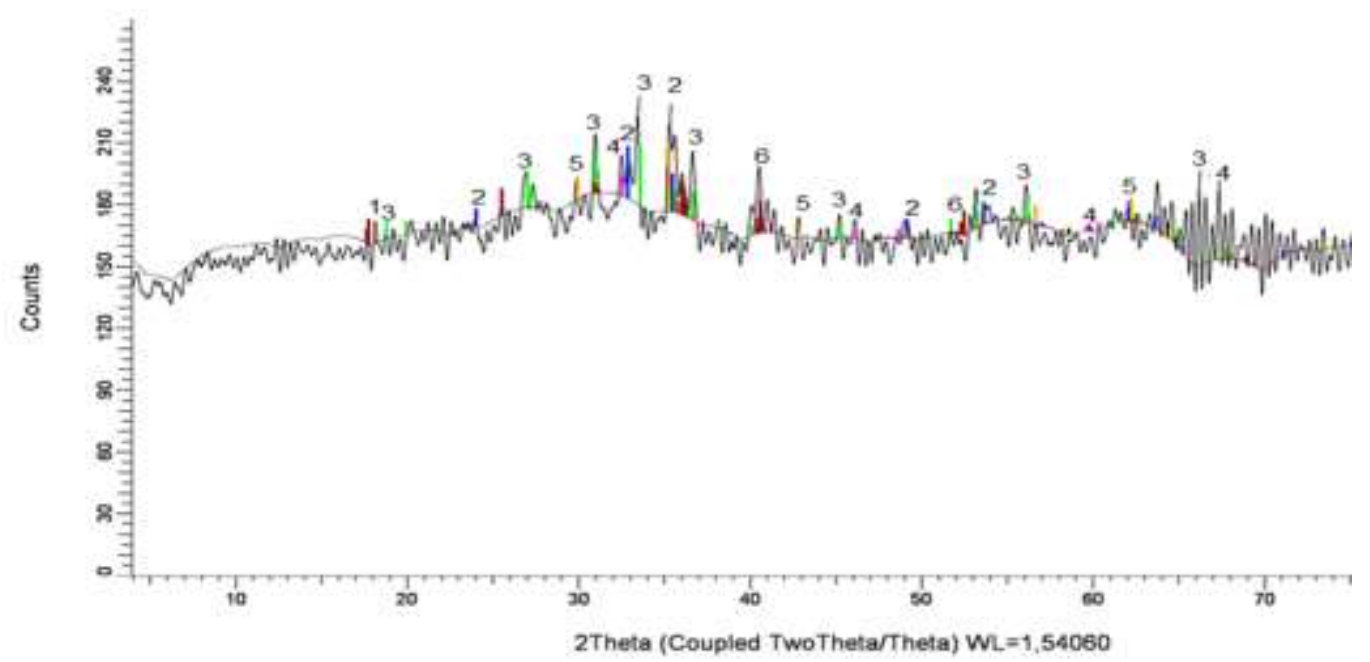

Figure 1. Diffractogram of electric smelting of ilmenite concentrate dust

Table 2 - Results of X-ray phase analysis of electric smelting of ilmenite concentrate dust (Fig. 1)

\begin{tabular}{cccc}
\hline Phase number in Figure 1 & Component & Formula & $\begin{array}{c}\text { Content, } \\
\text { rel. } \%\end{array}$ \\
\hline $\mathbf{1}$ & Iron Titanium Oxide & $\mathrm{Fe}_{2} \mathrm{TiO}_{5}$ & 35.78 \\
\hline $\mathbf{2}$ & Iron Titanium Oxide & $\mathrm{Fe}_{1.5} \mathrm{Ti}_{0.5} \mathrm{O}_{3}$ & 16.74 \\
\hline $\mathbf{3}$ & Franklinite, syn & $\mathrm{ZnFe}_{2} \mathrm{O}_{4}$ & 16.38 \\
\hline $\mathbf{4}$ & Magnesium Titanium Oxide & $\mathrm{MgTi}_{2} \mathrm{O}_{5}$ & 13.08 \\
\hline $\mathbf{5}$ & Magnesium Silicate & $\mathrm{Mg}_{2} \mathrm{SiO}_{4}$ & 10.27 \\
\hline $\mathbf{6}$ & Titanium Oxide & $\mathrm{TiO}_{2}$ & 7.76 \\
\hline
\end{tabular}

particles of lead and zinc oxides are present in the electric smelting of ilmenite concentrate dust. The image obtained in secondary electrons showed the fine-dispersedness of the object.

The results of the physical and chemical studies of the dust of electro smelting of ilmenite concentrate showed that part of the titanium is bound in hard-to-open anosovite that can be enclosed in a shell of amorphous silicon oxide. The finely dispersed state of the dust should contribute to the efficiency of the leaching of a harmful impurity - silicon.

The effect of the concentration of sodium hydroxide solution. The study of the effect of the concentration of sodium hydroxide solution on the extraction of silicon, chromium, manganese, zinc, and iron in the solution was performed in the concentration range $50-130 \mathrm{~g} / \mathrm{dm} 3$. The duration of the experiments was $2 \mathrm{~h}, \mathrm{~S}: \mathrm{L}=1: 5$. The stirrer rotation speed was $600 \mathrm{rpm}$.

Figure 4 shows the effect curves of the leaching degree of the controlled elements into the solution, the course of the curves shows that the most fully transferred silicon into the solution is $77.7 \%$. It is explained by the good solubility of sodium silicate in alkaline solutions.

The chromium leaching degree is significantly lower - 44.4\%. Franklinite decomposes to form the hydroxo complex $\mathrm{Zn}(\mathrm{OH})-3$ [7]. Silicon and iron, when present together in alkaline solution, can form various iron-silicon-containing complexes. This fact increases the solubility of iron in alkaline solution $[8,9]$.

The curves of metal oxides solubility dependence on alkali concentration have ascending and descending branches with a distinct maximum. The maximum is reached at sodium hydroxide concentration of $110-115 \mathrm{~g} / \mathrm{dm}^{3}$ under the conditions of the studies performed.

Thus, it has been experimentally established that the optimal concentration of sodium hydroxide for leaching dust from electric smelting of ilmenite concentrate is $110-115 \mathrm{~g} / \mathrm{dm}^{3}$.

An increase in the concentration of sodium hydroxide during the leaching of dust from the electric smelting of ilmenite concentrate resulted in a decrease in the output of the cake (Figure 5). 

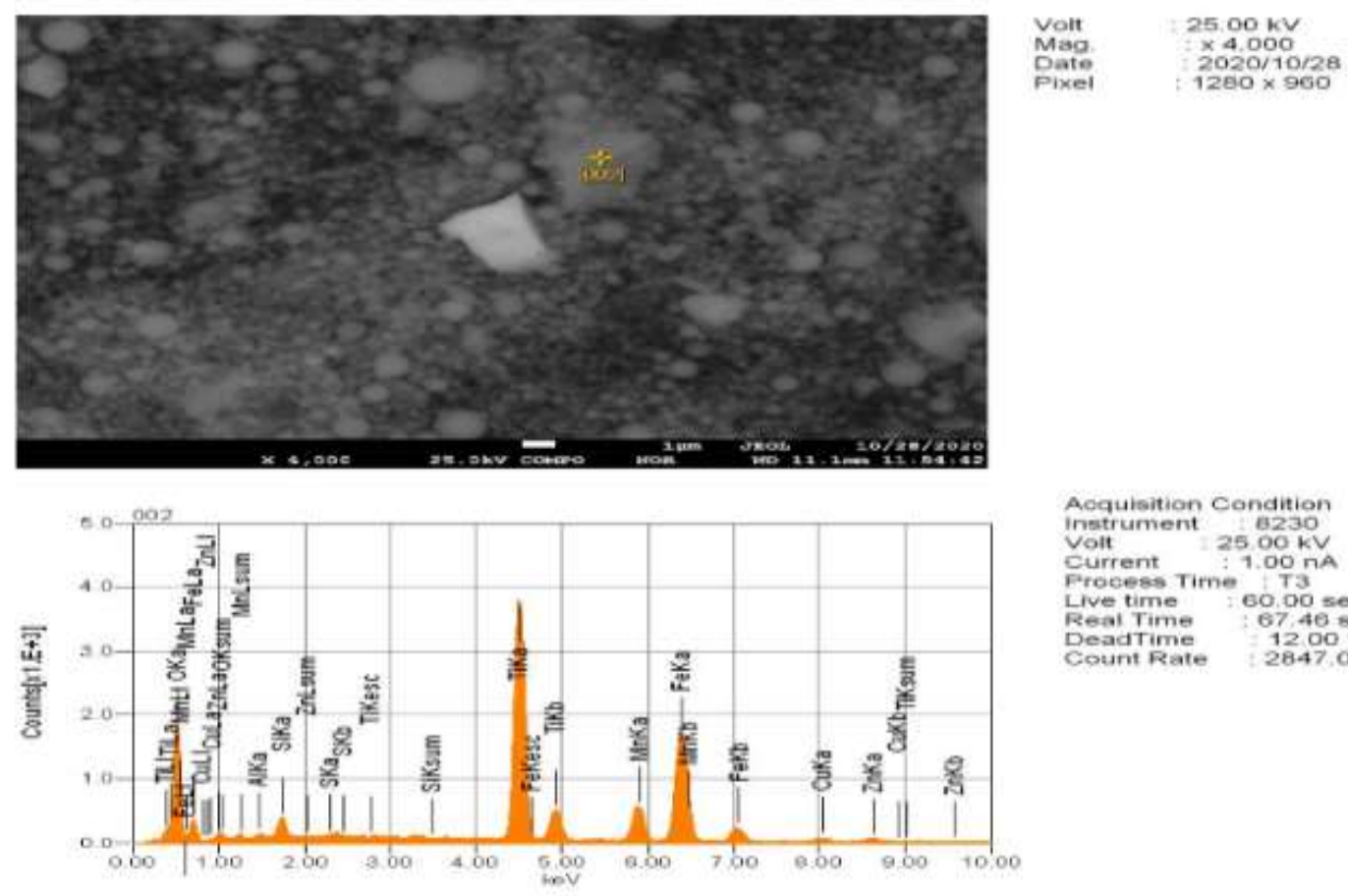

Aoquisition Condition instrument 6230 Current $2500 \mathrm{kV}$ Frocess Tirne T.00 TA Live time 60,00 seo. Real Time : $67.40 \mathrm{sec}$

$\begin{array}{ll}\text { DeadTime } & 1200 \% \\ \text { Count Rate } & 284700 \mathrm{cps}\end{array}$

\begin{tabular}{|c|c|c|}
\hline Ele & $m s \%$ & Elem \\
\hline 0 & 44.94 & $\mathrm{Mn}$ \\
\hline Al: & 0.31 & $\mathrm{Fo}$ \\
\hline si & 1,16 & $\mathrm{Cu}^{*}$ \\
\hline $\mathrm{s}^{\circ}$ & 0.10 & $\mathrm{Zn}^{*}$ \\
\hline$T$ & 24.19 & Tota \\
\hline
\end{tabular}

Figure 2 - Image and spectrum of anosovite particles [ $\left.\mathrm{MnO} 2 \mathrm{TiO}_{2}\right] \cdot\left[\mathrm{Fe}_{2} \mathrm{O}_{3} \cdot \mathrm{TiO}_{2}\right]$
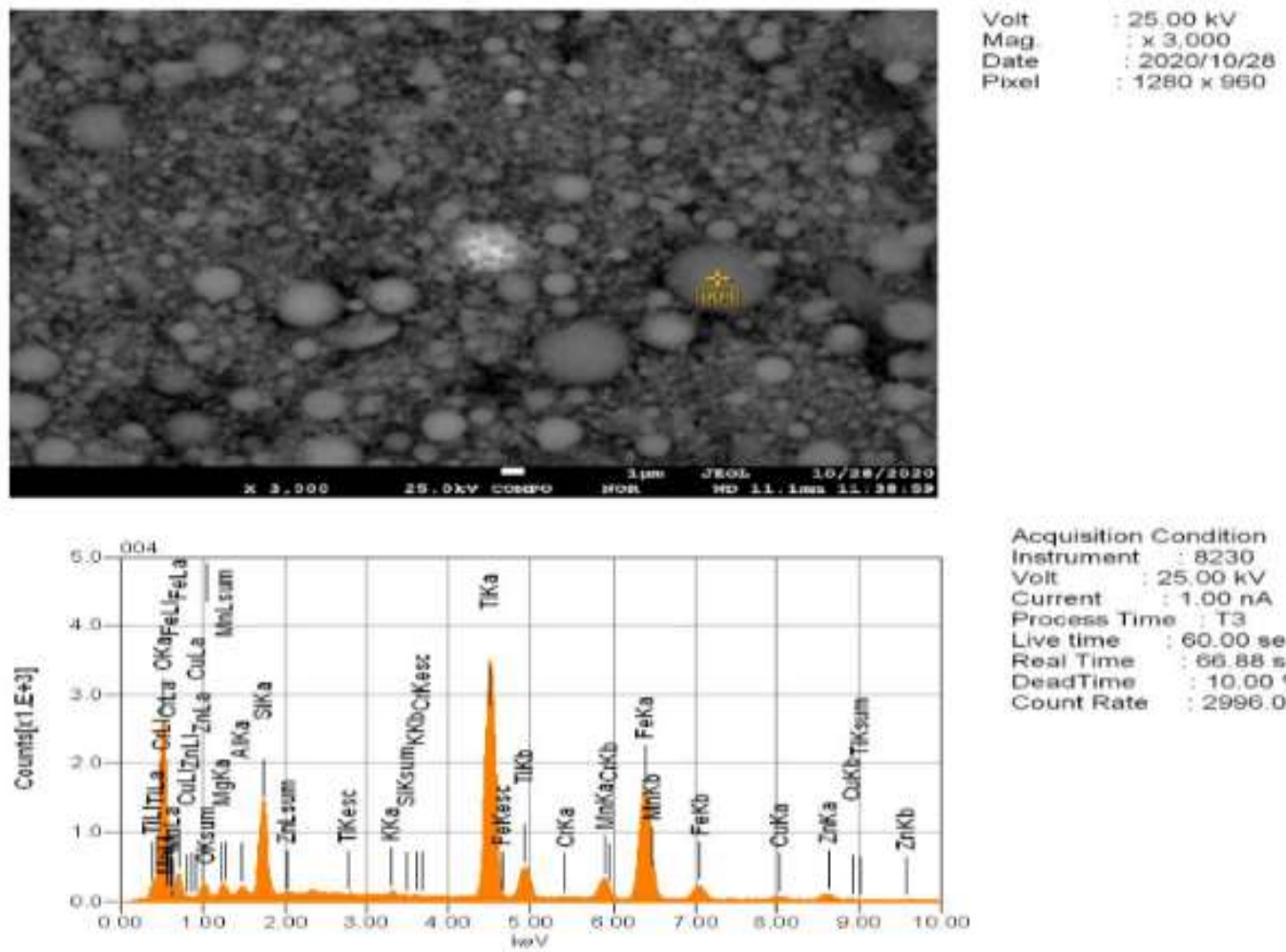

Acquisition Condition

instrument 8230

Volt : $25.00 \mathrm{kV}$

Current Time $1.00 \mathrm{TA}$

Live time: 60.00 sec

Real Time

DeadTime $10.00 \%$

Count Rate : $2996.00 \mathrm{cPs}$

\begin{tabular}{llll} 
Elements ms\% & \multicolumn{2}{l}{ Elements ms\% } \\
0 & 52.21 & $\mathrm{Mn}$ & 2.06 \\
$\mathrm{Mg}$ & 0.79 & $\mathrm{Fe}$ & 17.41 \\
$\mathrm{Si}$ & 4.55 & $\mathrm{Zn}$ & 2.08 \\
$\mathrm{~T}$ & 20.09 & Total & 100.00
\end{tabular}

Figure 3 - Image and spectrum of anosovite particles [ $\left.\mathrm{MnO}_{2} \mathrm{TiO}_{2}\right] \cdot\left[\mathrm{Fe}_{2} \mathrm{O}_{3} \cdot \mathrm{TiO}_{2}\right]$ in a shell $\mathrm{SiO}_{2}$ and $\mathrm{ZnO}$ 


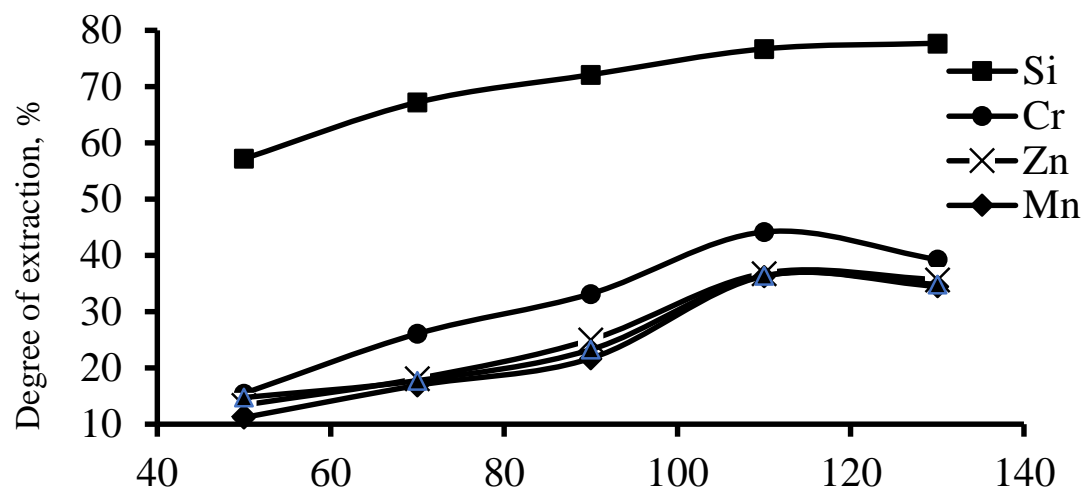

$\mathrm{NaOH}$ concentration, $\mathrm{g} / \mathrm{dm}^{3}$

Figure 4. Dependences of the leaching degree of the controlled elements into the solution on the concentration of sodium hydroxide

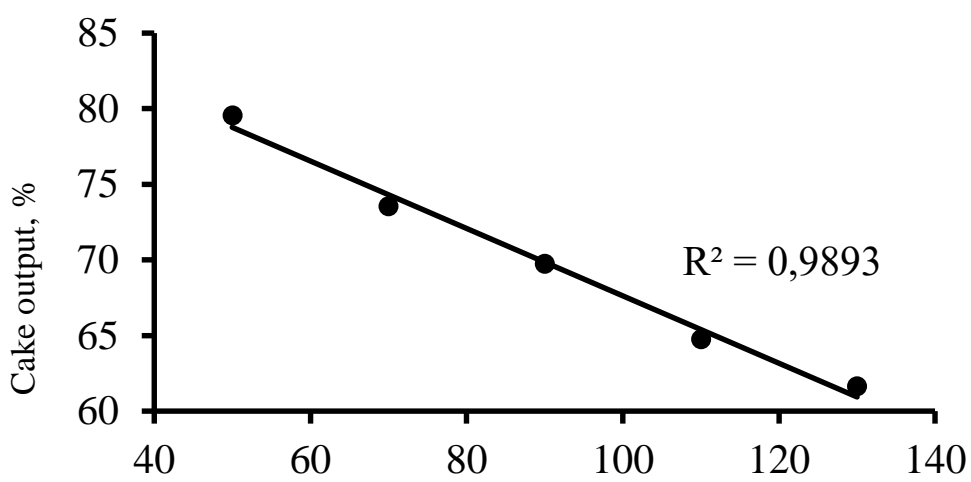

$\mathrm{NaOH}$ concentration, $\mathrm{g} / \mathrm{dm}^{3}$

Figure 5. Dependence of cake output on sodium hydroxide concentration

Figure 6 shows a diffractogram of the cake obtained by the effect of a solution with a concentration of $110 \mathrm{~g} / \mathrm{dm}^{3} \mathrm{NaOH}$ on the dust.

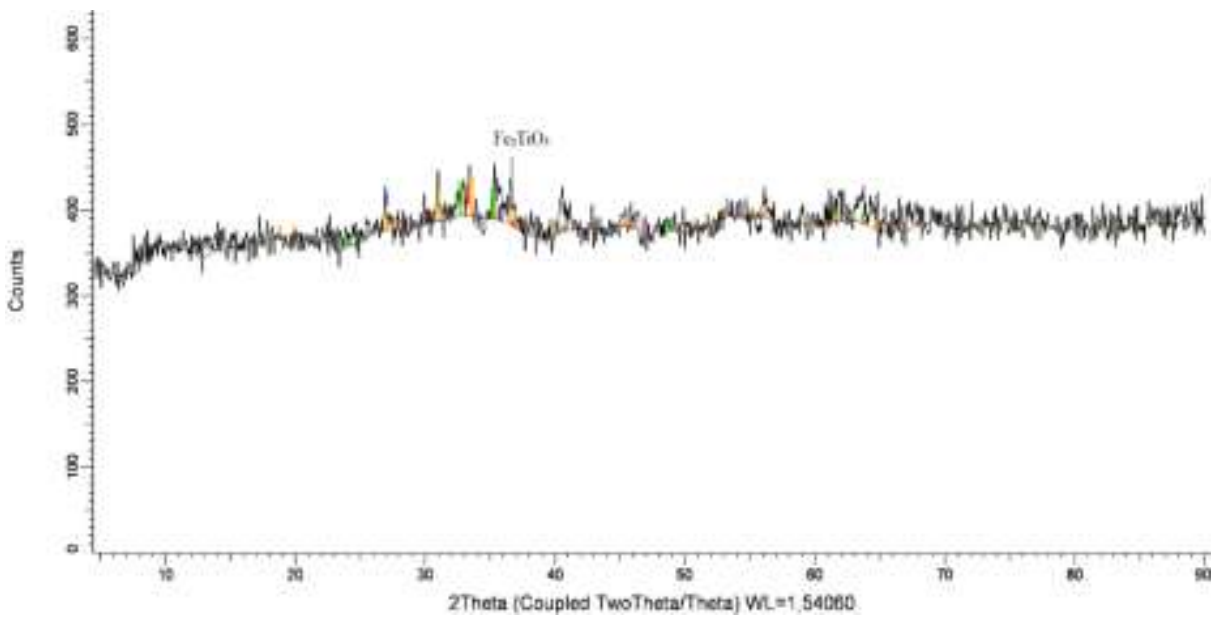

Figure 6. A diffractogram of the leaching product of electrowinning ilmenite concentrate dust $\left(110 \mathrm{~g} / \mathrm{dm}^{3} \mathrm{NaOH}, \mathrm{S}: \mathrm{L}=\right.$ $1: 5,80^{\circ} \mathrm{C}, 2 \mathrm{~h}$ ) 
The diffractogram type shows almost complete amorphization of the leaching product. The main phase - solid solution $\mathrm{Fe}_{2} \mathrm{O}_{3}-\mathrm{TiO}_{2}$ - was reliably determined. Presumably, it is titanium dioxide $\mathrm{TiO}_{2}$ and iron oxide $\mathrm{Fe}_{2} \mathrm{O}_{3}$.

Effect of the leaching process duration. The effect of the duration of silicon, chromium, zinc, manganese, and iron leaching from electric smelting of ilmenite concentrate dust was studied in the interval $15-120$ minutes, at $80{ }^{\circ} \mathrm{C}, \mathrm{S}: \mathrm{L}=1: 5$, sodium hydroxide concentration $130 \mathrm{~g} / \mathrm{dm}^{3}$. The stirrer rotation speed was $600 \mathrm{rpm}$.

Figure 7 shows that the degree of silicon transfer into the alkaline solution already in the first 15 minutes of leaching reaches a significant value of $57.7 \%$. At the same time, the extraction of other controlled impurities does not exceed $13-18 \%$.

Increasing the duration of alkaline dust treatment beyond 90 minutes has no significant effect.

$\mathrm{X}$-ray phase analysis in the initial period of the leaching process (15-30 minutes) showed the manifestation of the formed secondary components in the sludge. For example, iron hydroxide and oxides, pseudorutile (Figure 8, Table 3).

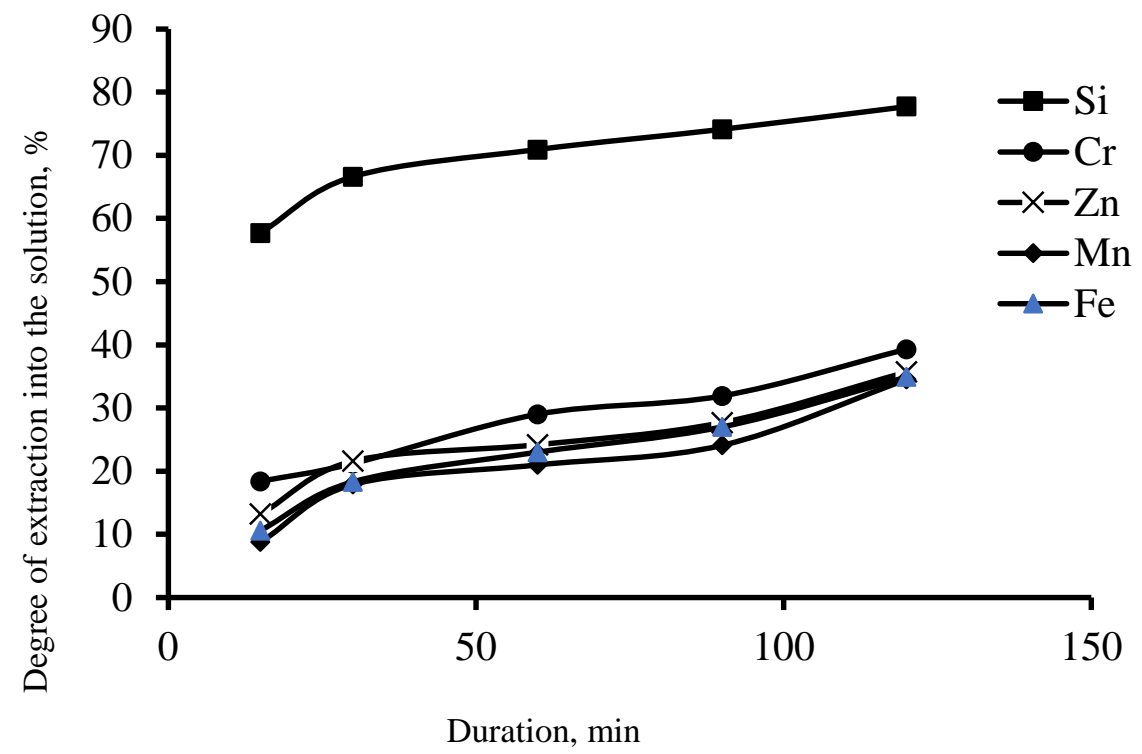

Figure 7. Effect of leaching duration on the extraction of silicon, chromium, zinc, manganese, and iron in the alkaline solution from the electric smelting of ilmenite concentrate dust

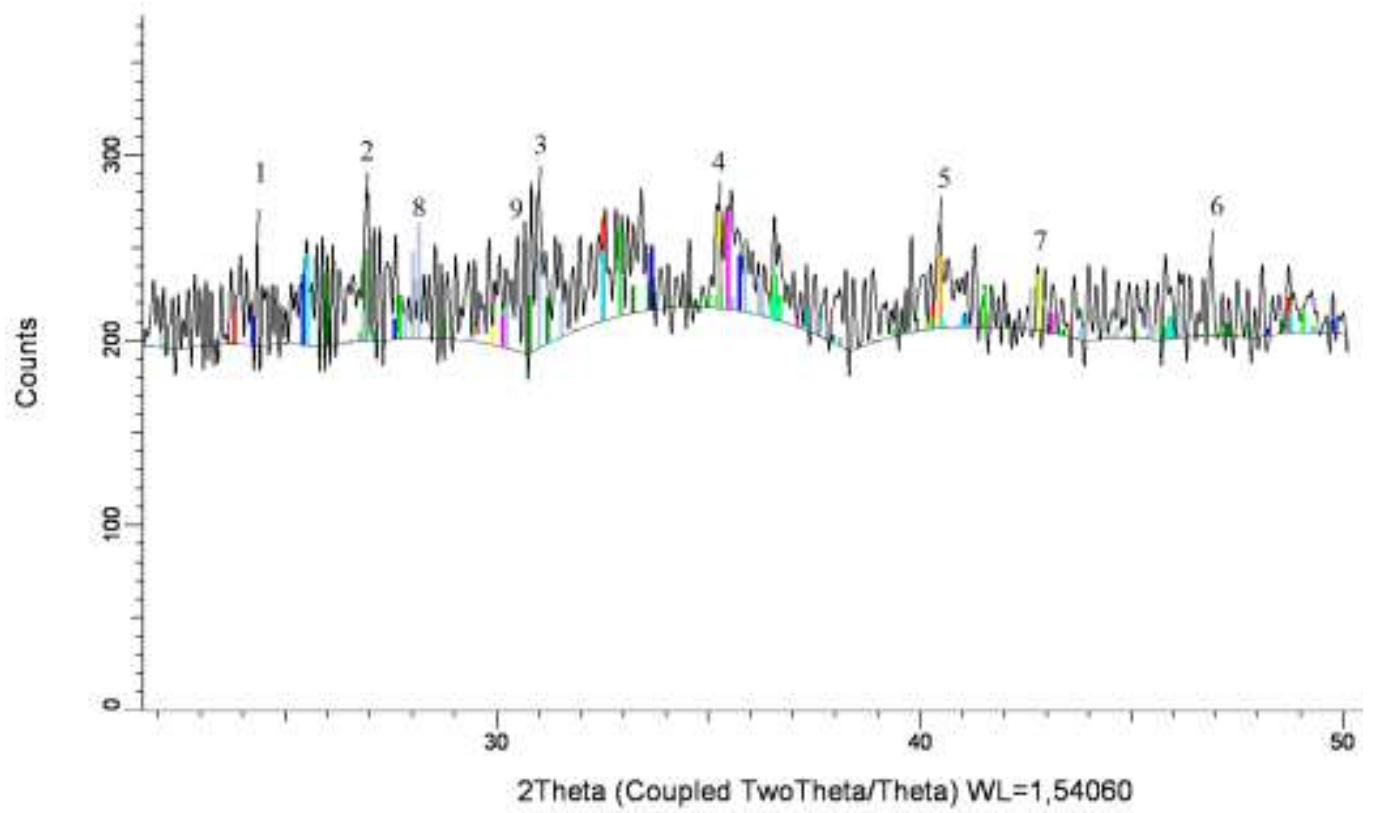

Figure 8. A diffractogram of the leaching product of electrowinning of ilmenite concentrate (duration $30 \mathrm{~min}, 80^{\circ} \mathrm{C}$, $\mathrm{S}: \mathrm{L}=1: 5, \mathrm{NaOH}$ concentration $130 \mathrm{~g} / \mathrm{dm}^{3}$ ) 
Table 3. Results of X-ray phase analysis of the leaching electrofusion dust product of ilmenite concentrate (Figure 8)

\begin{tabular}{cccc}
\hline Phase number in Figure 14 & Component & Formula & $\begin{array}{c}\text { Content, } \\
\text { \% }\end{array}$ \\
\hline $\mathbf{1}$ & Ilmenite & $\mathrm{Fe}_{1.04} \mathrm{Ti}_{0.96} \mathrm{O}_{3}$ & 17.79 \\
\hline $\mathbf{2}$ & Pseudobrookite & $\mathrm{Fe}_{2} \mathrm{TiO}_{5}$ & 15.89 \\
\hline $\mathbf{3}$ & Iron Oxide & $\mathrm{Fe}_{2} \mathrm{O}_{3}$ & 14.65 \\
\hline $\mathbf{4}$ & Iron Oxide Hydroxide & $\mathrm{FeO}(\mathrm{OH})$ & 12.52 \\
\hline $\mathbf{5}$ & Pseudorutile & $\mathrm{Fe}_{2} \mathrm{Ti}_{3} \mathrm{O}_{9}$ & 12.16 \\
\hline $\mathbf{6}$ & Iron Oxide & $\mathrm{Fe}_{3} \mathrm{O}_{4}$ & 10.59 \\
\hline $\mathbf{7}$ & Qandilite, syn & $\mathrm{Mg}_{2} \mathrm{TiO}_{4}$ & 7.69 \\
\hline $\mathbf{8}$ & Enstatite, ferroan & $\left(\mathrm{Mg}_{\left.1.561 \mathrm{Fe}_{0.439}\right) \mathrm{Si}_{2} \mathrm{O}_{6}}\right.$ & 6.59 \\
\hline $\mathbf{9}$ & Lead Oxide & $\mathrm{Pb}_{3} \mathrm{O}_{4}$ & 2.12 \\
\hline
\end{tabular}

Soluble compounds pass into the solution and the cake output decreases with an increase in the duration of the interaction of the electro smelting dust of the ilmenite concentrate with alkali (Figure 9).

Thus, the optimum leaching duration of electric smelting of ilmenite concentrate dust with sodium hydroxide solution is 1.5-2 hours.

Effect of temperature on the leaching process. The leaching temperature effect on the extraction of chromium, silicon, zinc, manganese, and iron in the solution was studied in the range of $40-95{ }^{\circ} \mathrm{C}$. The duration of the experiment was $2 \mathrm{~h}, \mathrm{~S}: \mathrm{L}=1: 5$, the concentration of sodium hydroxide solution was 130 $\mathrm{g} / \mathrm{dm}^{3}$. The stirrer rotation speed was $600 \mathrm{rpm}$.

It follows from the data in Table 4 that increase in temperature from 40 to $60{ }^{\circ} \mathrm{C}$ increases the silicon extraction degree by $23 \%$, further leaching temperature increase from 60 to $80{ }^{\circ} \mathrm{C}$ result in less significant silicon extraction increase - by $13 \%$. Leaching of dust at $95{ }^{\circ} \mathrm{C}$ enables to leach $82.8 \%$ of silicon into a solution, that is only $5 \%$ more than at $80^{\circ} \mathrm{C}$.

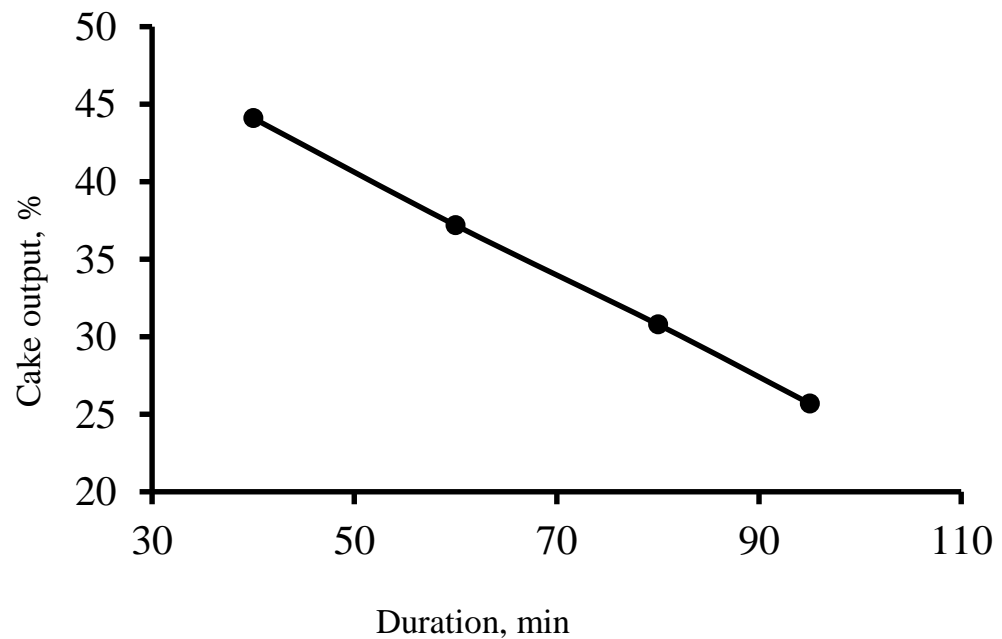

Figure 9. Cake output dependence on the leaching duration of electro-smelting dust of ilmenite concentrate $\left(80^{\circ} \mathrm{C}, \mathrm{S}: \mathrm{L}\right.$ $=1: 5, \mathrm{NaOH}$ concentration $130 \mathrm{~g} / \mathrm{dm}^{3}$ )

The behavior of other controlled impurities with changes in the temperature regime of the leaching process is similar to that of silicon. Thus, the optimal temperature for leaching electric smelting of ilmenite concentrate dust is $80-90^{\circ} \mathrm{C}$.

Effect of S:L ratio on the leaching process. The effect of the ratio of electric smelting of ilmenite concentrate dust to sodium hydroxide solution was studied in the range $1: 4 \div 10$ at $80{ }^{\circ} \mathrm{C}$, duration 120 min, stirring speed $600 \mathrm{rpm}$, the concentration of sodium hydroxide solution $130 \mathrm{~g} / \mathrm{dm}^{3}$. 
Table 4. Effect of the temperature of the electro-smelting dust leaching process of ilmenite concentrate on the degree of extraction of the controlled components in the solution, rel \%

\begin{tabular}{ccccccc}
\hline Temperature, ${ }^{\circ} \mathrm{C}$ & Cake output, $\%$ & $\mathrm{SiO}_{2}$ & $\mathrm{Cr}_{2} \mathrm{O}_{3}$ & $\mathrm{ZnO}$ & $\mathrm{MnO}$ & $\mathrm{Fe}_{2} \mathrm{O}_{3}$ \\
\hline $\mathbf{4 0}$ & 88.2 & 41.8 & 3.8 & 6.5 & 1.0 & 3.4 \\
\hline $\mathbf{6 0}$ & 74.4 & 64.7 & 32.8 & 19.4 & 16.5 & 17.8 \\
\hline $\mathbf{8 0}$ & 61.6 & 77.7 & 39.3 & 36.8 & 36.3 & 36.4 \\
\hline $\mathbf{9 5}$ & 51.4 & 82.8 & 42.0 & 43.8 & 43.5 & 41.1 \\
\hline
\end{tabular}

Analysis of the data in Table 5 showed that changing the ratio of solid to liquid 1:5 or more has little effect on the extraction of chromium, zinc, manganese, and iron in the solution.

The increase in the volume of alkaline solution per unit mass of dust from 1:3 to 1:8 results in an increase in the silicon extraction degree into the solution. Further increase in the sodium hydroxide flow rate has almost no effect on the transfer of silicon into the solution.

Thus, studies of the effect of the ratio of the solid phase to the liquid phase on the efficiency of the dust leaching process of electric smelting of ilmenite concentrate showed that the ratio of 1: 5 is optimal.

Table 5. Effect of the S: L ratio on the extraction of silicon, chromium, zinc, manganese, and iron into solution

\begin{tabular}{ccccccc}
\hline \multirow{2}{*}{ S:L } & Cake output, \% & \multicolumn{5}{c}{ Extraction rate, rel \%. } \\
\cline { 3 - 7 } & & $\mathrm{SiO}_{2}$ & $\mathrm{Cr}_{2} \mathrm{O}_{3}$ & $\mathrm{ZnO}$ & $\mathrm{MnO}$ & $\mathrm{Fe}_{2} \mathrm{O}_{3}$ \\
\hline $1: 3$ & 80.0 & 65.4 & 22.8 & 16.7 & 13.0 & 13.5 \\
\hline $1: 5$ & 61.66 & 77.7 & 31.3 & 35.7 & 34.5 & 34.9 \\
\hline $1: 8$ & 56.3 & 81.1 & 41.0 & 37.0 & 35.3 & 35.7 \\
\hline $1: 10$ & 54.7 & 82.1 & 42.4 & 37.7 & 35.1 & 35.4 \\
\hline
\end{tabular}

Thus, the optimum conditions to leach electric smelting of ilmenite concentrate dust were established experimentally: temperature $80-90{ }^{\circ} \mathrm{C}$, duration $90-120$ minutes, the ratio $\mathrm{S}: \mathrm{L}=1: 5$, the concentration of sodium hydroxide solution was $110-115 \mathrm{~g} / \mathrm{dm}^{3}$.

\section{Conclusions}

Physical and chemical studies of electric smelting of ilmenite concentrate dust showed that part of titanium is bound in hard-to-recover anosovite that can be enclosed in a shell of amorphous silicon oxide. The fine-dispersed state of the dust should contribute to the efficiency of harmful impurity - silicon leaching.

The optimum parameters of electric smelting dust leaching of ilmenite concentrate with sodium alkali were determined: $\mathrm{NaOH}$ concentration $-110-115 \mathrm{~g} / \mathrm{dm} 3 ; \mathrm{S}: \mathrm{L}-1: 5$; temperature $-80-90{ }^{\circ} \mathrm{C}$; duration 90-120 min. The silicon extraction degree into the solution was $77.7 \%$.

\section{Acknowledgement}

This work was supported by the Scientific Institutes of Metallurgy and Ore Beneficiation in Almaty, the Republic of Kazakhstan. Ministry of Education and Science of the Republic of Kazakhstan, grant number AP08855505.

Cite this article as: Ultarakova A.; Lokhova N.; Yessengaziyev A. (2021). Silica removal from waste of ilmenite concentrate pyrometallurgical processing. Challenges of Science. Issue IV, pp. 82-90. https://doi.org/10.31643/2021.12 


\section{References}

[1] [Electron. resource] - 2018. - URL: http://www.ereport.ru/articles/commod/titanium.htm, (Date of access 12.05.2018)

[2] Qiongsha Liu, Phil Baker, Hanyue Zhao. (2015) Titanium sponge production technology in China // Proceedings of the 13th World Conference on Titanium. San Diego, California, USA, August, pp. 177-182.

[3] Feng Gao, Zuoren Nie, Danpin Yang, Boxue Sun, Yu Liu, Xianzheng Gong, Zhihong Wang. (2018) Environmental impacts analysis of titanium sponge production using Kroll process in China. Journal of Cleaner Production. Vol.174, pp.771-779. doi: 10.1016/j.jclepro. - 2017.09.240.

[4] Chervony I.F., Listopad D.A., Ivashchenko V.I., Sorokina L.V. (2008) On the physical and chemical laws of the formation of titanium sponge. Scientific works "Donetsk National Technical University". Donetsk, Metallurgy. Issue. 10 (141). pp. 37-46.

[5] Teploukhov A.S. (2005) Prevention of pollution of water bodies with wastes of titanium-magnesium production/abstract of diss. Cand. tech. sciences.143 p.

[6] Reznichenko V.A., Averin V.V., Olonina T.V. (2010) Titanates. Scientific foundations, production technology. M.: Nauka. 267 p.

[7] Ponomareva E.I., Ogorodnikov Yu.l. (1973) Complex compounds of transfer metals in alkaline solutions. Alkaline hydrochemical methods in nonferrous metallurgy. Alma-Ata, Science. pp. 7-10.

[8] Bunchuk L.V., Goldman M.M., Ni L.P. (1973) About complexation in the system $\mathrm{Na}_{2} \mathrm{O}-\mathrm{Al}_{2} \mathrm{O}_{3}-\mathrm{Fe}_{2} \mathrm{O}_{3}-\mathrm{SiO}_{2}-\mathrm{H}_{2} \mathrm{O}$. Reports 1 . Alkaline hydrochemical methods in nonferrous metallurgy. Alma-Ata, Science. pp. 24-26.

[9] Panichkin A.V., Kenzhaliyev B.K., Kenzhegulov A.K., Imbarova A.T., Karboz Zh.A., Shah A. The effect of the catalytic layer composition on the hydrogen permeability of assymetric tantalum-based membranes]. Kompleksnoe Ispol'zovanie Mineral'nogo Syr'a = Complex Use of Mineral Resources. 2020. № 4 (315), pp. 82-95. https://doi.org/10.31643/2020/6445.40 